This is a preprint of an article accepted for publication in the Journal of the American Society for Information Science (c) 2008 [to appear in the August 2008 issue]

\title{
Trends in Internet Information Behavior, 2000-2004
}

\author{
Wayne Buente and Alice Robbin \\ wbuente@indiana.edu, arobbin@indiana.eduDuring \\ School of Library and Information Science \\ Indiana University Bloomington \\ 1820 E. 10th Street, Rm. 023 \\ Bloomington, IN 47405 \\ Submitted to \\ Journal of the American Society for Information Science
}

February 25, 2008

\begin{abstract}
By 2000, the Internet became an information and communication medium that was integrated in our everyday lives. Following an interdisciplinary approach, the research reported in this article analyzes the wide variety of information that people seek on the Internet and investigates trends in Internet information activities between 2000 and 2004, using repeated cross-sectional data from the Pew Internet \& American Life surveys to examine Internet activities that contribute to everyday life and their predictors. The objective is to deepen our understanding of Internet activities and everyday life and contribute to a growing body of research that utilizes large-scale empirical data on Internet use and everyday life. We ask: who is embedding the Internet into their everyday lives and what are the activities they pursue to facilitate everyday life? Findings demonstrate the differential returns for Internet use, particularly in key demographic categories. The study also contributes to emerging research on the digital divide, namely emphasis on the study of use rather than access to technology. Identifying trends in key Internet use dimensions enables policymakers to target populations who underutilize the potential of networked technologies.
\end{abstract}




\section{Introduction}

The research reported in this article analyzes the wide variety of information that people seek on the Internet and investigates trends in Internet information activities with attention to the context for these activities. We subscribe to Kari and Savolainen's (2003) admonition that "exploring the context and role of Internet searching is imperative if we aspire to genuinely understand real-life Web utilization” (p. 156). Moreover, as Fisher et al.'s (2005) work shows, people obtain many different types of information from multiple sources, use multiple channels, and in different locations, of which the Internet has become an important one (Harwood \& Rainie, 2004; Rainie, Fox, \& Fallows, 2003; Horrigan, Garrett, \& Resnick, 2004). The objective is to deepen our understanding of Internet activities and everyday life and contribute to a growing body of research that utilizes empirical data on Internet use and everyday life. (See, for example, Howard \& Jones, 2004; Katz \& Rice, 2002; Kraut, Brynin, \& Kiesler, 2006; Wellman \& Haythornthwaite, 2002).

The empirical research reported here originates in an analysis to evaluate theoretical frameworks, methodologies, and empirical findings in library and information science (LIS) and social science disciplines that have examined information behavior in a variety of contexts. We have concluded that an interdisciplinary approach that integrates theories of everyday information practices with theories from communication and media behavior, political science, social psychology, and sociology will substantially improve our understandings of information behavior, more generally, and guide the development of contextually-based models of everyday life information seeking on the Web, more specifically.

The research reported here focuses on everyday Internet use and trends between 2000 and 2004, using repeated cross-sectional data from the Pew Internet \& American Life (referred to as Pew hereafter) surveys to examine Internet activities that contribute to everyday life and their predictors. We examine how an individual acts in an information field containing multiple information channels and identify crucial explanatory variables and thereby suggest theoretical propositions that are generalizable across situations.

This period of four years represents a unique situation for conducting research into information, Internet use, and everyday life. The Internet and its users matured: technology became affordable, broadband penetration increased, and we domesticated computer use and the Internet (Cummings \& Kraut, 2002). Research on the Internet conducted during the 1990s evolved from studying who had access to the technology to asking whether technology or information should be the relevant focus of research on information behavior. Much of this research addressed issues of social inequality or, as it came to be known, the "Digital Divide," initially positing "first order effects" (the "primary digital divide") that privileged the technology to later investigating "second order effects" (the "secondary digital divide") that concerned skill and usage differentials when considering the benefits from advanced digital technology (see Compaine, 2001; Dewan \& Riggin, 2005; Gunkel, 2003; Hargittai, 2002, 2004; van Dijk \& Hacker, 2003).

Research on the Internet and Everyday Life section of this article briefly summarizes the origins of research on who uses the Internet, the relationship between traditional media use and Internet use, and how the Internet is used. The Research Methodology section describes our research strategy, including the questions we ask, empirical model, definitions, and the empirical data we rely on from the Pew Internet \& American Life project. Our efforts constitute an attempt to grapple with the elusive concept of "context" and the limitations of secondary data analysis. The Results section reports our findings on the Internet user population and their information activities. We explore the antecedents of Internet use, classify three types of information behavior through factor analysis, and study the effects of personal attributes, traditional media use, and technology on online behavior through logistic regression analysis. The Summary and Conclusions section summarizes our findings and extends them to discuss their contribution to recent research on inequality and public policy as it relates to access and use of Internet technology. We conclude that empirical research on Internet information behavior has implications for public policy regarding the information haves and have-nots: There is a need to ameliorate problems of what is now known as the "secondary digital divide," so that we can take advantage of the Internet's contribution to informing, communicating, and sharing.

\section{Research on the Internet and Everyday Life}

\section{Different Users, Different Uses?}

Beginning in the mid-1990s, the National Technical Information Administration (NTIA) issued a series of studies that focused attention on the technological opportunities available through physical access to computers and networks, telephones, PCs and the Internet across demographic groups and existing social inequalities related to technology access (NTIA, 1995, 1998, 1999, 2000). The scholarly and policy contributions that followed emanated from concerns about growing social inequality in the United States, what came to be known as the Digital Divide 
(see Buente, 2008, for a comprehensive review). Numerous studies helped frame public discussions about the Internet as an issue of physical access to computer and Internet technologies.

Internet penetration rapidly increased in the United States in the late 1990s and physical access to computer hardware became widely available in schools, public libraries, and the home. By 2000, scholarly research began a conceptual shift from its focus on inequality as it related to the technology to studying effective access and use (see Hargittai, 2002), leading to assessments that attributed inequality more to autonomy of use and skill level than to access to technology (Dewan \& Riggins, 2005). Research revealed that the Internet could still reinforce disparities between those who used information effectively and those who were under-informed and made less effective use of information in their daily lives, which, in turn, could influence how the Internet was situated in everyday life. The under-informed could, for example, view the Internet as an extension of infotainment, Krueger (2002) suggested, thereby reducing its potential as an information utility.

As such, it is useful to identify how the Internet is used and who is more likely to engage in these activities. For some, and indeed as many have argued, the Internet is associated with greater involvement in social, civic and/or economic pursuits (see Robbin, Courtright, \& Davis, 2004); however, the Internet is not a one-size-fits-all prescription for social improvement. Differences in Internet use may suggest certain profiles of Internet users more likely to engage in particular activities.

According to Howard, Rainie, and Jones (2002), people with different socio-demographic characteristics look for different content online. Their review of survey research on Internet use found "significant differences in use between men and women, young and old, those with different race and ethnicity, and those of different socioeconomic status” (p. 45). They also noted the importance of Internet experience and frequency of use for constructing a user typology.

Other researchers have examined specific demographic attributes to predict everyday life Internet use. Women tend to use the Internet more for social activities and less as an information utility (Brynin, 2006; Kennedy, Wellman, \& Klement, 2003). Women also tend to prefer email use over men and also use email for relationship building (Boneva \& Kraut, 2002; Rainie et al., 2000). Accordingly, they are less likely to get news and buy products online (Howard, 2004). Losh (2004) identifies digital gaps of access and use relating to gender, educational level, and labor force participation. In terms of a generational gap, older adults tend to lack key cognitive resources, thus reducing their willingness to utilize ICTs (Raban \& Brynin, 2006). Examining multiple national datasets, Robinson, DiMaggio and Hargittai (2003) note the importance of educational differences for accessing varying content on the web. In particular, the authors demonstrate how college educated Internet users consistently use the web for work, education, and other informing tasks. These users are also less likely to use the Internet for entertainment purposes. Income and racial differences are more likely explained through other demographics factors such as education and experience (see Mullis, Mullis, \& Cornille, 2007, who counter the Robinson et al., 2003, conclusion).

Other research has examined the relationship between the Internet and more traditional media. Nie and Erbring (2002) observe a substitution effect between greater Internet use and traditional media. On the other hand, other research has found a complementary relationship between Internet and traditional media use (Anderson \& Tracey, 2002; Lenhart \& Horrigan, 2003; Robinson, Kestnbaum, Neustadt, \& Alvarez, 2000; Stempel, Hargrove, \& Bernt, 2000).

Numerous studies cite the importance of Internet experience and skill with computer technology as a primary predictor of Internet use. Rainie and Bell (2004) report more "serious" uses of the Internet as experience with the medium is gained. Domesticating the Internet into our everyday life implies uses that reflect our personal tastes (Cummings \& Kraut, 2002); yet, domestication requires familiarity, which is only achieved through increasing use. Several studies reveal how user experience and time spent online shape the activities that are pursued on the Internet (Anderson \& Tracey, 2002; Howard, Rainie, \& Jones, 2002; Quan-Haase, Wellman, \& Haythornthwaite, 2002).

Research also indicates that one predictor of Internet use is the conduit. Slow dial up connections enable limited content experiences online compared to those with higher speed connections. As a result, broadband users spend more time online and engage in qualitatively different uses than users on dial-up connections (Davison \& Cotton, 2003; Horrigan \& Rainie, 2002; Rainie \& Bell, 2004).

\section{Classifying Internet Use: Communicating, Informing, Playing, and Buying}

Howard et al. (2002) analyzed Internet activities using data from the Pew Internet \& American Life project collected between March and August 2000 and classified these activities into four broad groups: fun, information utility, important life activities, and financial transactions. Research by Papacharissi and Rubin (2000) investigated why college students went online. Similar to Howard et al. (2002), they identified interpersonal utility, pass the time, 
information seeking, convenience, and entertainment through a factor analysis and determined that the strongest factors for using the Internet were information and amusement.

Stafford, Stafford and Schkade (2004) applied a uses and gratifications approach to assess AOL member Internet use. Their factor analysis of 45 potential uses and gratifications revealed three factors: process gratifications, content gratifications, and social gratifications. Process gratifications suggested a theme of surfing or searching the web. Content gratifications indicated an information component, and social gratifications involved interactions with people. In their study of Internet use and social capital, Shah, Kwak, and Holbert (2001) performed factor analysis to examine Internet use in a 1999 life style survey and identified four components: product consumption, information exchange, financial management, and social recreation. Johnson and Kaye (2003) examined why individuals access the web for political information and applied factor analysis to identify the online activities of shopping/finance, information seeking, recreational social connection, technical uses, and media entertainment (p. 313).

\section{Research Methodology}

The 2000 to 2004 time period of the Pew Internet \& American Life surveys makes it possible to examine trends in Internet information use. What trends emerge? Do we see differences between Internet and non-Internet users, and what factors predict Internet activity? Does experience with computer technology and the Internet make a difference in Internet information use? What do the findings suggest about social inequality, often called the digital divide as it relates to technology and the Internet, a discussion that has been prominent in the literatures of library and information science, mass communication, and sociology for more than a decade? This section discusses the research strategy we pursued to answer these questions.

\section{Modeling Information and Behavior}

Attempts to understand the relationship between information and behavior rely on causal models to reveal the relationships and the antecedent, mediating, and dependent variables of importance in a given context or situation. In our study, demography and the social and technological environment serve as the context for these information activities. ${ }^{1}$ Mass media are "treated as an integrated communication and social phenomenon" (Ruggiero, 2000, p. 7) that is part of the context of information use. Information technology (IT) is an integral part of information practices (Lievrouw, 2001; Orlikowski, 1992), although the technology itself has often been taken for granted as a dimension affecting information seeking; as Courtright (2007) emphasizes, IT "plays a dual role in context...as a shaper of information practices and the object of shaping by other contextual factors and by users themselves" (p. 22).

Scheufele, Nisbet, Brossard, and Nisbet (2004) summarize two dominant causal models that have been applied to examine the context of information behavior in sociological, political, and mass communication research, the "Standard Social Psychological Model" and the "Social Structural Model." ${ }^{2}$ Figure 1 below depicts these two models.

\begin{tabular}{|l} 
Subjective \\
Orientations $\longrightarrow$ Stimulus $\longrightarrow$
\end{tabular}$\longrightarrow \begin{aligned} & \text { Behavioral } \\
& \text { Orientations } \longrightarrow \text { Responses }\end{aligned}$

The StandardSocial Psychologica1 Model: The Causa1Ordering of Connections

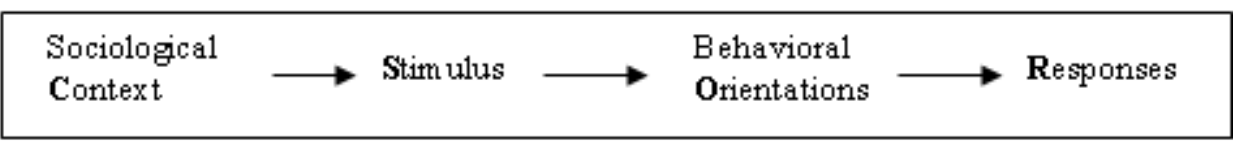

The Revised Socia1 Psychologica1 Model(Scheufele et a1., 2004)

\section{Figure 1. Standard and Revised Social Psychological Models}

The model in the upper panel is based on social psychology and concerns itself with characteristics of the individual such as attitudes and social categories. The model in the lower panel employs a more sociological framework, and its antecedents represent social structural variables such as the social environment or social networks. The difference between these two models is the emphasis placed on either social psychology or social structures to assess the role of behavior. 
To assess everyday Internet use and its role in an individual's information environment, we employ a simplified model that relies on the two models depicted by Scheufele et al. (2004). Socio-demographic characteristics, traditional media use, communication activities, and technology exposure serve as the context for predicting Internet information use. Figure 2 depicts these relationships between personal attributes, traditional media use, communication practices, technology, and Internet use acts. Our report on trends in Internet use between 2000 and 2004 focuses only on the relationships between sociodemographic factors, traditional media use, and technology that predict the Internet activities that users engage during this period. ${ }^{3}$

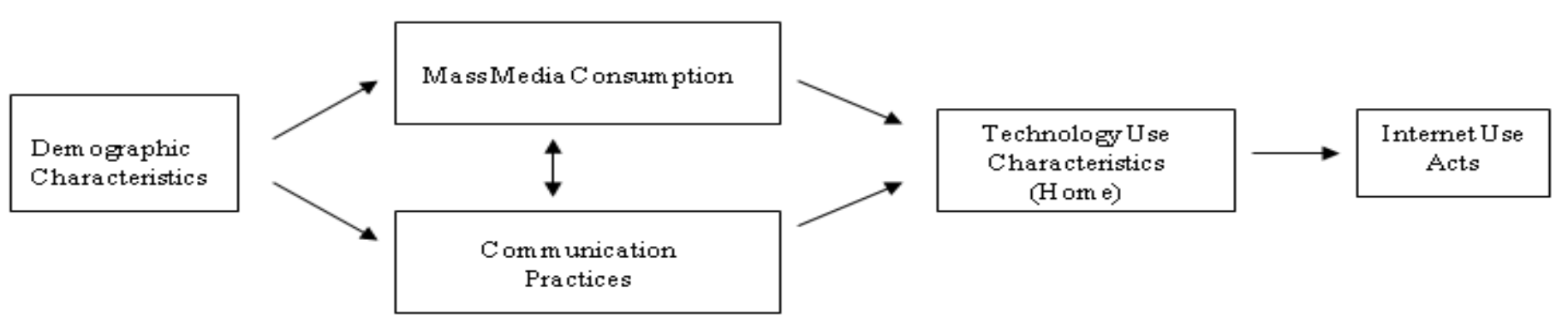

Figure 2. Model of Everyday Life Information Practices: Context for Internet Information Acts, 2000-2004

We recognize that there are well-known problems associated with assumptions about the causal order of events that take place (see Davis, 1985). We are also acutely aware, and do not claim to take account, of the array of contextual and situational factors that may potentially contribute to explaining Internet information behavior. We do not have direct access to the life-worlds of the respondents and to the meanings that they attribute to the worlds they inhabit. Although we can conjecture about intentionality, we cannot answer definitively the question "Why do people use the Internet?" We use the information behavior as a proxy for motivation, however, similar to uses and gratification research that has been carried out. The survey data we rely on also preclude developing and testing a more complex model of Internet information use practices. For example, cognitive and psychological antecedents might contribute to a more robust model of (a multi-) media use process; unfortunately, these data were not collected by the Pew surveys that we examine. This is discussed in more detail in the section on the survey data. Definitions

Digital divide research has placed a great emphasis on sociodemographic factors to explain computer and Internet access. Accordingly, we define demographic characteristics as race, income, education, gender, and age; these are the variables that have been associated with unequal access to technology. In this way, our model seeks to capture differential returns on Internet use as it relates to sociodemographic categories.

Media consumption is differentiated as either traditional media or new media use. We define traditional media as newspaper or television use; for the purpose of our model we employed survey questions that inquired about reading a newspaper or watching television habits. New media use is specifically identified as Internet use and type of connection because the type of Internet connection influences Internet use; we employed questions related to Internet experience, frequency of use, and the presence of high speed Internet in the home as opposed to public connections.

We define an information use act (activity) as the behavior associated with the type/source of information that the information actor identifies as having accessed on the Internet. These may include email, financial information, news, entertainment, products and services, and so on. The act also serves as a proxy for motivation. Internet information behavior is operationalized as engaged in an Internet use activity. Internet information activities can be categorized as media interaction (e.g., information dissemination and transactions through political and government web sites, newspapers, information about the weather, financials, health, etc.) and computer-mediated interaction (e.g., email, Usenets, chat rooms, online forums for public deliberation).

Although many Internet activities are pursued online, the literature review reveals how these information use activities converge on common categorizations for media use: the Internet offers an opportunity to communicate, inform, entertain, and shop. What is not so obvious is who employs the Internet for these particular activities? Are there differences between those who use the Internet to inform versus those who use it to entertain? Here we describe in more detail the survey data. 
Empirical Data: Contents and Limitations of the Pew Internet and American Life Surveys

We rely on a series of eight large national tracking surveys on Internet use that were conducted by the Pew Internet \& American Life project between March 2000 and December 2004. Three surveys were conducted during a November election period (2000, 2002, 2004). The remaining five surveys were conducted annually in March: one at the start of the Iraq War (2003) and the other four between March and May (2001, 2002, 2003, 2004). See details on the number of respondents and the dates when these eight surveys were administered in Appendix Table A1. All surveys utilized random digit dialing to reach adults across the continental United States, interviewing between 1,500 and over 3,000 respondents in each survey; we report unweighted counts for all survey data. The March 2001 survey is unique because it is longitudinal panel data drawn from the March 2000 survey respondents; as a result, the March 2001 survey has fewer respondents compared to the other surveys that we examined. Pew administered two 2003 March surveys: a special Iraq War and its regular daily tracking survey. The March 2003 Iraq War survey has two series of Internet information use questions with items similar to those we analyze in the seven other surveys (this latter series of question is the subject of other research that we have conducted and is reported separately).

These surveys have important advantages. They are large probability samples of respondents 18 years and older conducted over a period of several years. Random digit dialing telephone interviews capture the complexity of respondents' Internet and non-Internet use, many different types of information activities, exposure, information technology ownership and intensity of use (proxy for motivation), and the different settings in which information activities take place. These surveys ask similar or identical questions over time.

However, important caveats must be offered about these Pew surveys: There is what we might call a "dissonance" between the theory that underlies the design of the survey data collection and uses to which these data will be put in future research (secondary data analysis). Empirical research, no matter whether inside or outside a discipline, will always reflect the theoretical framework(s) employed by a researcher. It is nearly always the case, for example, that secondary analysis of data collected by non-LIS researchers will be unable to satisfactorily or fully answer questions posed by library and information science. Part of our intention, however, in conducting and reporting this secondary analysis of the Pew Internet \& American Life surveys is to encourage just this type of assessment of crossing disciplinary boundaries and to bring attention to the contribution of large scale survey data to advancing library and information science research in information behavior.

Another example of this "dissonance" is helpful. The social psychological model that we described above suggests that cognitive and affective factors contribute to Internet use. Self-efficacy of one's ICT capabilities, as one of our reviewers suggested, would be a valuable psychological measure, and, indeed, researchers have noted that psychological factors have not been examined to explain Internet use (Broos \& Roe, 2006; Stanley, 2003). Unfortunately, one of the limitations of the Pew surveys is the dearth of questions addressing motivation, confidence, and self-reliance on computers. Despite the lack of adequate psychological indicators in the dataset, however, we follow the argument by van Dijk (2005) that socioeconomic factors "are primary and evident reasons [contextual factors] for motivation” (p. 39). ${ }^{4}$

An additional problem faced by secondary analysts of the Pew data is that, although there is a core of items that are included across all surveys, the number and types of use acts for which data are collected are not the same across the four year period. Questions about specific information activities vary from survey to survey. Earlier surveys conducted in 2000 and 2001 draw on a larger and more diverse Internet activities question set. Later surveys, such as November 2002, March 2003 Iraq War, and November 2004, ask fewer Internet activity questions. Only two Internet use questions were asked in all eight surveys; however, most Internet use questions appear in at least half the surveys that we analyze. Appendix Table A2 identifies Internet activities, percentage rates of use, and survey year the question appeared. Because not every Internet information activity is asked in every survey during the period that we examine, our study of changes over time between 2000 and 2004, reduces our analysis to a smaller subset of activities.

"Missing data" constitute another problem because most respondents did not engage in all or even most Internet information use acts for which the Pew surveys collected data. Information use activities are based on selfreports for which there are well-known problems (Krosnick, 1999; Suchman \& Jordan, 1990). It is also important to note that Pew varied wording for questions thought to describe information activities that held the same meaning for respondents; differences in phrasing were not intended to suggest different meanings to the respondents; however, no cognitive interviewing was carried out to determine this (personal communication, August 2, 2005, between coauthors and Pew Study Director John Horrigan).

Although it would be ideal to develop a survey instrument capable of capturing all the nuances of previous research, as well as to capture the questions of interest to library and information science, it is often difficult and unpractical to implement on a large scale. Our analysis differs from the intent of the original Pew researchers. 
However, we believe the Internet activity questions in particular capture the wide variety of ways people use the Internet. Of the 42 Internet activities asked in any of the eight surveys, only 15 appear in at least four of the eight surveys. As a result, the consistency of Internet assessment among respondents is lacking. Due to these limitations, we apply our analysis at a gross level and our interest is in the large scale trends in Internet information behavior. The research reported here focuses on more specific questions of Internet use and trends for information acts that are captured in either all eight or the majority of the surveys.

Finally, we conjecture that some of the unmeasured heterogeneity that we find is most likely the result of the design of the survey and the unobservables that the model does not capture. Again, to emphasize, secondary data analysis will nearly always impose (sometimes significant) constraints on what analysts can do with data that they have not themselves collected.

\section{Statistical Procedures}

One challenge to working with a large series of data over an extensive time period is synthesizing the findings. Making sense of a diverse source of Internet activities requires reducing the survey questions to a set of common dimensions (factors). This can be accomplished by using factor analysis on the Internet activities for each survey year. Factor analysis is a statistical technique to discover latent patterns in a dataset. Factor analysis provides a heuristic device to empirically assess categories that relate variables together. It is essentially a data reduction technique "to see whether there is a set of factors that can explain the variation of the variables under study" (Hinton, 2004, p. 305). By applying factor analysis to the online activity questions, we can begin to unravel a set of general characteristics that Internet users share, reducing the large set of Internet activities to a smaller set of exploratory factors. Mislevy (1986) provides the reasoning for applying exploratory factor analysis.

The usual objectives in factor analysis are (a) to determine the number of factors that provide a satisfactory fit to the observed correlation matrix and (b) to estimate the regression coefficients of the observed variables on the factors - all this, it is hoped, leading to a more parsimonious and meaningful explication of the patterns of interrelationship among the observed variables. (p. 3)

Determining these factors for each survey offers an opportunity to locate a parsimonious and meaningful explanation of the patterns of interrelationship among the Internet activities. In so doing, we establish the importance of the representative Internet activities of interest described above. By observing how each Internet activity "loads" on each factor, we get a sense of how online actions characterize different dimensions of Internet use. The last step of the analysis will closely examine these Internet activities along common demographic characteristics and experience with technology that may or may not contribute to Internet use.

In a previous section of the paper, we depicted a conceptual model based on mass communication and mass political behavior research to specify the proper antecedents contributing to Internet use. To this end, we use a binary logistic regression model because we rely on dichotomous dependent variables. ${ }^{5}$ We apply a model that isolates selected antecedents in the following categories for independent variables (demographics, traditional media use, Internet usage/skill and computer hardware) and study the effects of these variables on Internet activities. The dependent variables are "Get news online," "Buying a product online," and "Going online to pass the time." The dependent variable was coded one if respondents engaged in the activity for that survey year. All variables in the model are categorical except for age, income and number of years online. ${ }^{6}$ The binary logistic regression demonstrates the relative effect of different demographics and other antecedents to determine whether a user engaged in the activity in question.

\section{Results}

Recent research on Internet use has called for more theoretically driven studies designed to understand particular uses of the Internet (Shklovski, Kiesler, \& Kraut, 2006; Wellman, 2004). Kennedy et al. (2003) urge an integrated perspective:

People come to the Internet as people, and not as minds-and-fingers devoid of gender, socioeconomic status, race and the like. They have backgrounds that inform their access to the Internet and how they use the Internet. They have needs, constraints and abilities that affect what they want to do online and what they can do. (p. 89)

With this in mind, our goal is to identify who is online and what do they do? Key for this work is determining important specific Internet activities that meaningfully contribute to everyday life. Using repeated cross-sectional data, the paper seeks to identify major trends for Internet respondents, activities and dimensions.

Who is Online?

To provide a context for Internet use, we first examine who is and is not online during the four years. Appendix Table A3 provides selected demographic characteristics of Internet user or non-users and shows that 
Internet users vary demographically from their non-Internet counterparts in consistent ways over the four year period.

The proportion of men to women remains relatively unchanging throughout the surveys for Internet users. However, more women $(56.1 \%$ avg.) than men $(43.9 \%$ avg.) are non-users of the Internet. Internet users are predominantly white. The number of online Hispanic users declines from $7.5 \%$ to $5.4 \%$. African Americans Internet users maintain their presence at 8\% to 9\%, but register a decline in the March 2001 panel (5.3\%) and the March 2003 Iraq War survey (5.9\%). At the same time, however, Hispanics and African Americans also increased their presence among non-Internet users (9.3\% to $12.5 \%$ for Hispanics and $12.6 \%$ to $14.6 \%$ for African-Americans). Internet users are noticeably younger than non-Internet users by at least 10 years. For both populations, the average age shows an increasing trend. However, the age gap between Internet and non-Internet users has declined during this time. In addition, non-Internet users are more represented among respondents with less than a college degree and those who earn less than $\$ 20,000$ per year; this is not surprising given the fact that Internet users are generally better educated thereby leading to higher incomes.

\section{Exploring the Antecedents of Internet Use}

The appeal of the Internet depends on a variety of factors that influence how online life is experienced. Prior research shows that age, gender, experience, education, and race tend to predict Internet use (Clancy, 2002; DiMaggio, Hargittai, et al., 2004; Losh, 2004; Raban \& Brynin, 2006; Robinson, DiMaggio, \& Hargittai, 2003). Our analysis focuses on some of these factors and their influence on particular forms of Internet use.

The Role of Experience. One likely strong predictor is experience. The number of years of Internet use may serve as a proxy for digital literacy skills (Hargittai, 2004). According to Horrigan and Rainie (2002), the number of years a person has been online is "a strong predictor of the amount of time they spend online, the frequency with which they $\log$ on, and the scope and frequency with which they engage" (pp. 138). Using similar Pew data, Horrigan and Rainie categorized the experience level of Internet users into three categories: "newcomers" ( $<1$ year online), "mid-range" (2-3 years online), and "long wired" (3 or more years) (p. 140). The upper panel of Table 1 shows the four year trend between 2000 and 2004 of the experience level of Internet users for these categories of experience using the Internet.

[Table 1 about here]

There is a sharp increase in experienced Internet users starting in 2002. During both the March and November 2002 surveys, the percentage of experienced Internet users increased dramatically from prior years, $52.0 \%$ to $72.2 \%$, an increase of more than 20 percentage points. This indicates an overall increase of Internet users in 1999, as these same users are now experienced users by 2002. The rise of these "long wired" users almost tripled from 2000 to 2004 (29.4\% to 84.6\%). By November of 2004, less than five percent of Internet users could be considered "newcomers."

Location. Internet activity is also explained by location. In addition to the experience data, the two lower panels of Table 1 display the frequency of going online from home and work. For users who go online from home, there is an increase only for those logging on several times a day. From 2000 to 2004, the percentage of users who reported being online more than once a day increased from $23.3 \%$ to $30.2 \%$. Yet for those who use the Internet less frequently from home, the percentage remained relatively stable. For those who go online from work, the story is similar to home users. The percentage of users who go online more than once a day from work increased from 40.6\% in March 2000 to 59.0\% in November 2004.

Traditional Media Use and the Internet. Prior research suggests a relationship between Internet use and traditional media. For seven of the eight surveys, two survey questions asked about newspaper reading and TV news watching for the previous day. Another question inquired whether the respondent went online yesterday. If we assume engagement in these activities yesterday constitutes a situation of habitual media use, then we depict an application of everyday life information practices.

Table 2 shows habitual media use for all surveys on reading a newspaper, watching TV, and going online.

[Table 2 about here]

The first row of the table indicates that an average of $60 \%$ of the Internet users went online yesterday. In addition, there is a steady decline for respondents who read a daily newspaper yesterday. The highest percentages were between March 2000 and March 2001 (43.4\%, 45.1\% , and 50.6\%), falling to 42.4\% in November 2004.

There is, however, a different story for watching TV news. From 2000 to 2004, we see incremental gains from $56.0 \%$ to $64.0 \%$. In general, Internet users tend to be more likely to watch the TV news regularly than to read a 
newspaper (t-statistic (p<.001): Mar2000=-8.151, Nov2000=-18.076, Mar2001=-5.436, Mar2002=-14.186, Nov2002=-13.864, Mar-May2003=-13.072, Nov2004=-13.059). This result supports work by Kraut, Kiesler, Boneva, and Shklovski (2006) showing that people who use the Internet for entertainment or information purposes are also the heaviest television viewers (p. 81). As such, the Internet is a more likely candidate to supplement TV news as an information utility.

\section{Internet Information Activities: What Are People Doing Online?}

The information use acts selected for analysis met two criteria: Each Internet act appeared in at least five of the eight surveys and the Internet activities reflected different dimensions of Internet use. According to our research, these dimensions are information, communication, leisure, and financial transactions; they are deserving of closer attention because they account for most of the use of the Internet. Four of the most popular Internet activities and their suggested classification are described below and also bold-faced in Appendix Table A2 "Percentage Rates of Internet Activities by Survey Year, 2000-2004.”

Dimensions of Internet

Information Use

Communication

Information

Leisure

Financial (Transactions)
Representative Internet Activity

Send or receive email

Get news online

Go online for no particular reason, just for fun or to pass the time

Buy a product online, such as books, music, toys or clothing

As Appendix Table A2 indicates, sending and reading email constitutes the most popular Internet activity. At least $90 \%$ of Internet users engage in sending or reading email, and this activity has remained consistent in its popularity in every survey. Sending and receiving email demonstrates the effectiveness of the Internet as a communication tool. The role of the Internet as a source for news and political information steadily increased over the four year time period (59.5\% to 68.8\%). Get news online represents an information dimension. At least $60 \%$ of Internet users spent their time going online for no particular reason; the Internet also appears to play a leisure role: It is a good place to relax and have fun. Lastly, the Internet helps facilitate e-commerce transactions; buying a product online shows an increasing trend from 2000 to 2004.

Categorizing Internet Use Activities. Eight separate factor analyses were carried out on dichotomous data, one for each survey. Internet activities were coded one if they engaged in the activity or zero if they did not. According to Appendix Table A2, sending and receiving email engages over 90\% of Americans. Given the overwhelming dominant nature of sending and receiving email as an Internet activity (Horrigan, 2006; Kraut, Mukhopadhyay, Szezypula, Kiesler, \& Scherlis, 1999), this activity was excluded from factor analysis. ${ }^{7}$ Three of $^{2}$ the four March questionnaires (March 2000, 2001, and March-May 2003) collected data on a larger number of Internet activities than did later surveys (see Appendix Table A2). Accordingly, the more diverse a set of Internet activities, the more dimensions of Internet use. Six of the eight Pew surveys (March 2000, Nov 2000, March 2001, March 2002, March 2003 Iraq War, and March-May 2003) revealed at least five factors. Given the smaller number of Internet acts, the remaining two surveys located only two dimensions of Internet use. For more details on the factor analyses for these years, see Appendix Tables A4, A5, and A6.

Despite the inconsistencies over time in the questions asked about Internet activities, the factor analysis time and again categorized Internet activities around a factor of information utility. A second, remarkably consistent, factor was entertainment, which emerged as a factor in six of the eight surveys despite the variety in the number and type of questions regarding Internet use. The third most prevalent factor was financial transactions, appearing as a factor in five of the eight surveys. Over the span of the eight surveys, these three factors tended to emerge along the lines identified by Howard et al. (2002). For the purpose of this paper, we focus only on the three most consistent dimensions among the eight surveys: information utility, leisure/fun, and financial transactions. ${ }^{8}$

The Internet as an Information Utility. As mentioned above, information utility is a very consistent dimension of Internet use. The information utility factor appears in all eight surveys (see Table A4 "Information Utility Factor for Survey Years, 2000-2004”). The most problematic interpretations occur, however, in the November 2002 and March 2003 Iraq War surveys; these two surveys also ask the fewest Internet activity questions, thereby disrupting the consistency of factors revealed across the surveys. For example, the November 2002 and March 2003 Iraq War factor analyses for information utility also include the "Buy a product online activity.” This results because there were too few Internet activity questions to sufficiently show the appropriate variation in 
information utility and financial transactions. As such, the factors that appear in the November 2002 and March 2003 Iraq War surveys appear to capture both information utility and financial transactions use; for these two particular surveys, the factor is thus interpreted as an information transaction.

Table A4 also highlights the "Get news online" activity in each information utility/transactions factor. In half of the surveys, "Get news online" represents the first or second highest factor loading score. For the remaining surveys, "Get news online" still loads on the appropriate information utility factor, despite the inconsistency of survey questions asked during the 2000 to 2004 time period. We argue that Table A4 demonstrates the importance of "Get news online" as an information utility for citizens today.

The Internet as Leisure and Fun. Between 2000 and 2003, leisure and/or fun emerged as a consistent dimension of Internet use. The factor analysis grouped certain activities, such as downloading music and playing games, into a recreational form of Internet behavior. For the November 2002 and November 2004 surveys, respondents were not asked Internet use questions that reflected a leisure orientation. As a result, this factor appears in only six of the eight surveys. In March 2002, only one Internet activity, "Playing games online," captured the leisure dimension, which is to be expected since it was the only leisure question asked. Table A5 "Leisure Factor for Survey Years, 2000-2003" shows the leisure factor for those surveys in which it was present. One particular Internet activity consistently appears, "Go online for no particular reason." In general, this Internet act loads reasonably well when it is present. Except for the November 2000 survey, "Going online to pass the time" weighted at least .5 in the leisure factor. As such, "Go online for no particular reason" signifies the importance of the leisure/fun dimension for Internet use.

Internet for Financial Transactions. A common reason for individuals to go online is to pursue ecommerce products and services. These particular activities relate to buying products, buying and selling stocks and other e-commerce services. Due to the unique nature of the November 2002 and March 2003 Iraq War surveys, the information utility and financial transactions factors are better interpreted as an information transaction factor. However, the remaining surveys reasonably reflect a good interpretation of a financial transactions factor. Table A5 "Financial Transactions Factor for Survey Years, 2000-2003" identifies the financial and information transactions factors present in the surveys. In addition, Table A5 highlights the most consistently present Internet activity throughout the March 2000 to March-May 2003 period. "Buy a product online, such as books, music, toys or clothing" has factor loadings above .55 for five of the seven surveys. In some cases, it is the top loading Internet activity for the financial transactions factor in a survey year. "Buy a product online, such as books, music, toys or clothing" thus emerges as an effective representation of the financial transactions dimension of Internet use.

\section{Predicting Online Behavior}

During 2000 to 2004, we domesticated the Internet; it became part of our everyday lives. The question is no longer about who can access the Internet and where, no longer a question of technical access, of connectivity. Rather, now it is more important to determine the quality of that access: "effective and efficient access," argue Hargittai and Shaffer (2006), which they define as "the ability [skills] to locate content online" (p. 433). Savolainen (2002) too draws attention to the critical need for "network competence." As such, it would be useful to identify particular populations that would benefit from improving the quality of their access if we are able to predict information utility, financial transactions, and entertainment by utilizing the three Internet activities specified by the factor analysis. (Given the popularity of email as an Internet activity, it is not necessary to attempt to predict its use. Horrigan and Rainie (2002) and Kraut et al. (1999) have reported that many novice Internet users utilize email first and foremost and continue its use.)

If there are demographic differences for getting news online, the gap resembles the "knowledge gap" hypothesis in communication research (Gaziano, 1997; Viswanath \& Finnegan, 1996). Work by Robinson and Martin (2005) and DiMaggio, Hargittai, et al. (2004) suggest that ICTs contribute to a growing knowledge gap. Demographic differences for buying a product online and going online to pass the time also imply that certain Internet information uses are specific to particular advantaged or disadvantaged users. This final section examines, in more detail, whether socio-demographic characteristics contribute to everyday life information environments for these three Internet activities of information, leisure, and e-commerce transactions ("Get news online," "Go online for no particular reason, just for fun or to pass the time," and "Buy a product online, such as books, music, toys, or clothing”).

Before discussing the results, we provide a brief note on interpretation. The results should be interpreted as the following. Significant values are bold-faced. Values that are positive indicate that the independent variables 
contribute toward predicting getting news online (the dependent variable). Consequently, a negative value reduces the likelihood for the independent variable to contribute to the dependent variable. online."

Getting News Online. Table 3 presents the results from eight logistic regression analyses on "Getting news

[Table 3 about here]

Having a college degree significantly increases the probability of getting news online. This result is consistent throughout the later survey years (2002 to 2004). In addition, age also emerges as a significant predictor from 2003 to 2004. Younger individuals are more likely to get news online than those who are older during these years.

The other significant trend shows the importance of Internet use and skill. Logistic regression shows that experience counts, even when socioeconomic characteristics are accounted for: the more experience, the higher the probability that Internet users get news online. Traditional media also contributes to getting news online. From 2002 to 2004, either reading a newspaper online or watching TV news predicted getting news online. Having a broadband connection achieved significance in 2004, indicating the growing impact of broadband on Internet use. These results seem to suggest a disparity between the information rich and information poor. As such, the domestication of the Internet into our everyday lives does appear to contribute to social inequality related to ICTs.

Buying a Product Online. The economic characteristics of Internet users are evident in the results of the seven logistic regression analyses shown in Table 4. Income is a consistent, positive, and noteworthy predictor of buying a product online.

[Table 4 about here]

Having a higher income significantly increases the probability that the Internet user will buy products online. Those who are better off financially will use the Internet as a way to pursue financial transactions. These Internet users are also younger, as age contributes negatively toward buying a product online for almost all survey years. There are significant differences among college and high school graduates for buying products online. Except for the March 2001 survey, college users were more likely to go online to buy products than those with a high school degree. The results also suggest that female users may be more likely to buy products online, as three of the eight surveys (March 2001, November 2002, March-May 2003) have a positive, significant value for being female. Like getting news online, more time spent on the Internet also increases the likelihood of buying products online. Prior research indicates that more experience online tends to lead to greater trust in online transactions (Horrigan, 2006; Howard et al., 2002; Raban \& Brynin, 2006). Race and use of traditional media did not make statistically significant contributions consistently across the seven surveys.

Those with broadband connections significantly predicted buying products online for the 2002 surveys, yet broadband connection was not significant in the 2003 surveys. This is most likely due to an early adopter effect, as the emergence of broadband motivated users to engage in ecommerce over getting news online or going online for fun. Why this e-commerce effect is not present in 2003 is more difficult to explain. Perhaps, the Iraq War in 2003 reduced the desire of broadband users to engage in e-commerce due to long term concerns with the economy.

Going Online to Pass the Time. The last set of analyses focuses on the entertainment aspect of Internet use. Results are shown for logistic regression analyses on "Going online to pass the time" for five of the eight surveys. Table 5 shows a significant difference between recreational uses of the Internet by education.

[Table 5 about here]

College educated users are significantly less likely to use the Internet for entertainment than high school educated users. This result is significant and consistent throughout the five surveys and is similar to other findings (Robinson, DiMaggio, \& Hargittai, 2003). Education is negatively related to entertainment and personal uses. Being younger is more likely to engage in passing the time online. Four of five surveys show a significant decrease in the probability of passing the time online as one gets older. For two surveys (March 2001 and March-May 2003), respondents with lower income are less likely to go online to pass the time. Unlike the other Internet activities examined, having fun online is not associated with Internet experience; in only one of the five surveys (March 2003 Iraq War) was this effect significant, and experience actually contributed negatively toward passing the time online. Novice Internet users will more likely use the Internet for leisure activities until their skill/experience increases. For example, Howard and Massanari (2007) demonstrate that search engine sophistication can develop through greater Internet use and experience to overcome socioeconomic status. In the November 2004 survey, broadband users were more likely to use the Internet for entertainment; this can be attributed to online gaming and other multimedia entertainment options available for those with high speed Internet connections. 


\section{Summary and Conclusions}

This paper set out to identify different aspects of Internet use and also to determine who engages in these particular activities. The important questions no longer involve access to the Internet, but rather address the secondary digital divide (Hargittai, 2002) and other forms of inequitable information uses which concern abilities related to searching, selecting, processing and applying information. By isolating key Internet activities that reflect important dimensions of Internet use, we hope to contribute to the debate about how the Internet situates itself in everyday life. Controlling for socioeconomic variables, we specified a model that accounted for Internet use and experience and also the rollout of broadband technology. In doing so, we capture additional measurements of context in everyday life information use.

As Internet technology continues to domesticate itself, what is the long term social impact (Brynin \& Kraut, 2006)? Using repeated cross-sectional data provides the opportunity to address this question. Although we cannot imply causality to our findings, the results suggest opportunities for further research on Internet use. There are suggested user profiles for the major trends that we discovered for the three key Internet activities examined here.

Over the four year time period, empirical evidence supports the evidence of a secondary digital divide. If we accept the premise that getting news online appropriately represents Internet use as an information utility, our study suggests that Americans who are older, not college educated, do not monitor news through traditional media, and are not experienced or frequent Internet users will be on the digital divide. It is clear that buying a product online is only available for those with higher socio-economic status and a fair amount of Internet skill. Furthermore, going online to pass the time is more likely for those with lower socio-economic status. Our findings also are consistent with work by Robinson and Martin (2005), who analyzed the General Social Survey cross-sectional series for 2000 through 2004:

...[u]sage of Internet information websites was found among those with higher years of education and higher vocabulary scores supporting the concern of social commentators and communication scholars who fear that IT does function to widen the "knowledge gap" between the information rich and poor in society. At the same time it may be increasing an "entertainment gap" between these groups as well. (p. 30)

The results of our study also show that, in contrast to many early Internet studies which raised concerns about a digital divide, use is not related to race/ethnicity. Race was not a consistent independent variable to predict Internet use during 2000 to 2004. Gender studies have also emphasized the significant male-female differences in use of the Internet; our data show some predictive power for getting news online and buying a product online, but were not consistent over the four years.

Our findings support, in part, research by Howard et al. (2002), who stated that "the most useful predictors of the activities users enjoy online are their length of experience with the Internet and their frequency of logging on from home" (p.71). For two of the three Internet activities, this was indeed true. However, those who go online for fun tend to be inexperienced users. The findings presented here do show that both demographic differences and Internet use/skill disparities influence the way people interact with Internet content.

There are some limitations of the current research. The use of TV news as a proxy for television viewing does not capture the full spectrum of TV viewing. Also, our analysis was cross-sectional rather than longitudinal, making it difficult to observe changes in media use in individuals from 2000 to 2004. Related to this point, our choice of variables to examine context for Internet use was limited to the core questions asked in each survey year. Unfortunately, these questions are very general. Accordingly, the findings presented here represent only broad Internet trends. Furthermore, questions on specific Internet activity are not present in all surveys. This resulted in less than ideal interpretations of certain factors. Nevertheless, the three dimensions of Internet activity replicated prior classifications attempts.

It is an ambitious goal to attempt to identify the "who" and "what" of Internet life. Nevertheless, inquiring about these aspects of Internet life supplies a useful base to draw further insights about how the Internet embeds in our lives. More specifically, we sought to determine the answers to two questions: Who is embedding the Internet into their everyday lives? What are the activities they pursue to facilitate everyday life? Our results indicate there are still socioeconomic differences between Internet users and nonusers from 2000 to 2004. However, among Internet users there is evidence that use is increasing for minorities and older Americans. To determine if the Internet is contributing to qualitative changes for Americans requires a closer examination of what people do online.

We argue that the Internet is more likely to contribute to significant changes and opportunities for everyday life if it acts as an information utility or helps to facilitate transactions. For example, a key premise for a successful democracy is an informed citizenry. Buying products and other services in the convenience of your home allows greater time for other everyday life tasks. In contrast, going online to pass the time is unlikely to produce equivalent qualitative changes. By focusing on selected Internet activities, we demonstrate the presence of knowledge and 
entertainment gaps for certain demographic predictors. This suggests that the revolutionary power of the Internet may not be available for all. Yet, it is not enough to stop here. Other important questions await examining the when, where, why and how.

We also hope that our model will contribute toward understanding the policy implications of the digital divide. The model presented here links antecedent and intervening factors that explain differential uses of the Internet as opposed to access to the Internet. The growing interest in the secondary digital divide would benefit from our findings relating sociodemographic characteristics to informative or entertainment use.

Our analysis of these Pew Internet \& American Life surveys contributes to our understanding of what policies need to be implemented in order to take advantage of the Internet's contribution to informing, communicating, and sharing. Identifying trends in key Internet use dimensions enables policymakers to target populations who underutilize the potential of networked technologies. Information is a key component of any democracy. If the Internet is to succeed as an important information utility for citizens, then government initiatives need to target certain populations less likely to see the Internet for anything more than an entertainment medium. Only by emphasizing the importance of both Internet access and effective use will this medium achieve its potential for informing democracies, sustaining economies, and building community. Our future research is designed to identify these more specific linkages between Internet information use, skills, and democratic informedness.

\section{Acknowledgements}

We would like to thank reviewers for their useful suggestions and our colleague John Paolillo of the School of Library and Information Science at Indiana University Bloomington for his advice. Or course, we alone are responsible for the analysis.

Notes:

${ }^{1}$ Other aspects of the context include social and cognitive psychological attributes of the individual; however, the Pew data do not include this information, as we explain in the next section

${ }^{2}$ Robbin and Buente manuscript in progress, which provides a detailed discussion of contextual models used in cognitive, social psychological, and social structural approaches.

${ }^{3}$ We integrate communication practices into our analysis in our study of Internet use behavior during the Iraq War; this manuscript is in progress.

${ }^{4}$ Van Dijk (2005) argues that motivation is influenced by a set of resources: material, time, social, mental, emotional, and cultural. Of these resources, one's position in the labor market, education and household are the primary reasons for explaining motivation.

${ }^{5}$ Binary variables have two categories and are often used to indicate whether an event occurred or not (Long, 1997, p. 1). Our dependent variables are dichotomous and indicate whether an Internet activity was or was not undertaken by the respondent.

${ }^{6}$ Income was a categorical variable transformed into a weighted scale using the following values:

$5 \quad$ Less than $\$ 10,000$

$15 \$ 10,000$ to under $\$ 20,000$

$25 \$ 20,000$ to under $\$ 30,000$

$35 \$ 30,000$ to under $\$ 40,000$

$45 \$ 40,000$ to under $\$ 50,000$

$63 \$ 50,000$ to under $\$ 75,000$

$87.5 \$ 75,000$ to under $\$ 100,000$

$125 \$ 100,000$ or more

For the March 2000 and November 2000 surveys, number of years online was weighted with the following scale:

$0 \quad$ Less than 6 months

1 Greater than 6 months and less than two years

2.5 Two to three years

5 Three or more years

${ }^{7}$ Because sending and receiving email is so popular, this Internet activity lacks sufficient variation to be an effective variable for factor analysis, especially for dichotomous variables.

${ }^{8}$ Other factors were revealed but were not consistent across all eight surveys. In addition, we focus on those factors that correspond to prior Internet use classifications. 


\section{References}

Anderson, B., \& Tracey, K. (2002). Impact (or otherwise) of the Internet on everyday British life. In B. Wellman \& C. A. Haythornthwaite (Eds.), The Internet in everyday life (pp. 139-163). Malden, MA: Blackwell Pub.

Boneva, B., \& Kraut, R. (2002). Email, gender and personal relationships. In B. Wellman \& C. A. Haythornthwaite (Eds.), The Internet in everyday life (pp. 372-403). Malden, MA: Blackwell Pub.

Broos, A., \& Roe, K. (2006). The digital divide in the Playstation generation: Self-efficacy, locus of control and ICT adoption among adolescents. Poetics, 34(4-5), 306-317.

Brynin, M. (2006). The neutered computer. In R. E. Kraut, M. Brynin \& S. Kiesler (Eds.), Computers, phones, and the Internet: Domesticating information technology. Oxford; New York: Oxford University Press.

Brynin, M., \& Kraut, R. (2006). Social studies of domestic information and communication technologies. In R. E. Kraut, M. Brynin \& S. Kiesler (Eds.), Computers, phones, and the Internet: Domesticating information technology (pp. 3-18). Oxford; New York: Oxford University Press.

Buente, W. (2008). Alternative models of the digital divide: Antecedents, outcomes, and consequences. Qualifying paper submitted to the Indiana University Bloomington School of Library and Information Science, January 2008. Available: http://ella.slis.indiana.edu/ wbuente/Buente_qualifyingpaper.pdf

Clancy, R. E., \& United States Bureau of the Census. (2002). A nation online: How Americans are expanding their use of the Internet. New York: Novinka Books.

Compaine, B. M. (2001). The digital divide: Facing a crisis or creating a myth? Cambridge, Mass.: MIT Press.

Courtright, C. (2007). The challenge of context in information behavior research. Annual Review of Information Science and Technology, 41, 273-306.

Cummings, J. N., \& Kraut, R. (2002). Domesticating computers and the Internet. Information Society, 18(3), 221231.

Davis, J. (1985). The logic of causal order. Beverly Hills, CA: Sage Publications, Inc.

Davison, E., \& Cotton, S. R. (2003). Connection discrepancies: Unmasking further layers of the digital divide, First Monday, $\quad 8(3)$ r Retrieved $\quad$ August $1, \quad 2007$, from http://www.firstmonday.org/issues/issue8_3/davison/index.html

Dewan, S., \& Riggins, F. J. (2005). The digital divide: Current and future research directions. Journal of the Association for Information Systems, 6(12), 298-338.

DiMaggio, P., Hargittai, E., Celeste, C., \& Shafer, S. (2004). Digital inequality: From unequal access to differentiated use. In K. M. Neckerman (Ed.), Social inequality (pp. 355-400). New York: Russell Sage Foundation.

Fisher, K., Naumer, C., Durrance, J., Stromski, L., \& Christiansen, T. (2005). Something old, something new: Preliminary findings from an exploratory study about people's information habits and information grounds. Information Research, 10(2). Retrieved February 2005, from http://informationr.net/ir/10-2/paper223.html

Gunkel, D. J. (2003). Second thoughts: Toward a critique of the digital divide. New Media \& Society, 5(4), 499-522.

Hargittai E. (2002). Second-level digital divide: Differences in people's online skills. First Monday, 7(4). Retrieved November 1, 2007, from http://firstmonday.org/issues/issue7_4/hargittai/index.html

Hargittai, E. (2004). Internet access and use in context. New Media \& Society, 6(1), 137-143.

Hargittai, E., \& Shafer, S. (2006). Differences in actual and perceived online skills: The role of gender. Social Science Quarterly, 87(2), 432-448.

Harwood, P., \& Rainie, L. (2004, March). People who use the Internet away from home and work (Memo). Retrieved May 10, 2005, from http://www.pewinternet.org/pdfs/PIP_Other_Places.pdf

Hinton, P. R. (2004). Statistics explained. London: Routledge.

Horrigan, J. (2006). Portraits of American Internet use. In R. E. Kraut, M. Brynin \& S. Kiesler (Eds.), Computers, phones, and the Internet: Domesticating information technology (pp. 21-31). Oxford; New York: Oxford University Press.

Horrigan, J. B., \& Rainie, L. (2002). The broadband difference: How online Americans' behavior changes with high speed Internet connections at home. Washington, DC: Pew Internet and American Life Project. Retrieved September 21, 2002, from http://www.pewinternet.org/pdfs/PIP_Broadband_Report.pdf

Horrigan, J., Garrett, K., \& Resnick, P. (2004). The Internet and democratic debate. Retrieved October 28, 2004, from http://www.pewinternet.org/pdfs/PIP_Political_Info_Report.pdf

Howard, P. N. (2004). Embedded media. In P. N. Howard \& S. Jones (Eds.), Society online (pp. 1-27). Thousand Oaks, CA: Sage.

Howard, P. N., \& Jones, S. (2004). Society online: The Internet in context. Thousand Oaks, CA: Sage. 
Howard, P. N., \& Massanari, A. (2007). Learning to search and searching to learn: Income, education, and experience online. Journal of Computer-Mediated Communication, 12(3), 846-865.

Howard, P. N., Rainie, L., \& Jones, S. (2002). Days and nights on the Internet. In B. Wellman \& C. A. Haythornthwaite (Eds.), The Internet in everyday life (pp. 45-73). Malden, MA: Blackwell Publisters.

Johnson, T. J., \& Kaye, B. K. (2003). Around the World Wide Web in 80 ways. Social Science Computer Review, 21(3), 304-325.

Kari, J., \& Savolainen, R. (2003). Toward a contextual model of information seeking on the Web. The New Review of Information Behaviour Research, 4(2), 155-175.

Katz, J. E., \& Rice, R. E. (2002). Social consequences of Internet use: Access, involvement, and interaction. Cambridge, MA: MIT Press.

Kennedy, T., Wellman, B., \& Klement, K. (2003). Gendering the digital divide. IT\&Society, 1(5), 72-96.

Kraut, R. E., Brynin, M., \& Kiesler, S. (Eds.). (2006). Computers, phones, and the Internet: Domesticating information technology. Oxford; New York: Oxford University Press.

Kraut, R., Kiesler, S., Boneva, B., \& Shklovski, I. (2006). Examining the effect of Internet use on television viewing. In R. E. Kraut, M. Brynin \& S. Kiesler (Eds.), Computers, phones, and the Internet: Domesticating information technology (pp. 70-83). Oxford; New York: Oxford University Press.

Kraut, R., Mukhopadhyay, T., Szczypula, J., Kiesler, S., \& Scherlis, B. (1999). Information and communication: Alternative uses of the Internet in households. Information Systems Research, 10(4), 287-303.

Krosnick, J. (1999). Survey research. Annual Review of Psychology, 50, 537-567.

Krueger, B. S. (2002). Assessing the potential of Internet political participation in the United States. American Politics Research, 30(5), 476-498.

Lenhart, A., \& Horrigan, J. B. (2003). Re-visualizing the digital divide as a digital spectrum. IT\&Society, 1(5), 2339.

Lievrouw, L. A. (2001). New media and the "pluralization of life-worlds.” New Media \& Society, 3(1), 7-28.

Long, J. S. (1997). Regression models for categorical and limited dependent variables. Thousand Oaks, CA: Sage.

Losh, S. C. (2004). Gender, educational, and occupational digital gaps 1983-2002. Social Science Computer Review, 22(2), 152-166.

Mislevy, R. J. (1986). Recent developments in the factor analysis of categorical variables. Journal of Educational Statistics, 11(1), 3-31.

Mullis, R. L., Mullis, A. I., \& Cornille, T. A. (2007). Relationships between identity formation and computer use among black and white emerging adult females. Computers in Human Behavior, 23(2), 415-423.

National Telecommunications and Information Administration. (1995). Falling through the net: A survey of the "have-nots" in rural and urban America. Washington, DC: U.S. Department of Commerce.

National Telecommunications and Information Administration. (1998). Falling through the net II: New data on the digital divide. Washington, DC: U.S. Department of Commerce.

National Telecommunications and Information Administration. (1999). Falling through the net: Defining the digital divide. Washington, DC: U.S. Department of Commerce.

National Telecommunications and Information Administration (2000). Falling through the net: Toward digital inclusion. Washington, DC: U.S. Department of Commerce.

Nie, N. H., \& Erbring, L. (2002). Internet and society: A preliminary report. IT\&Society, 1(1), 275-283.

Orlikowski, W. (1992). The duality of technology: Rethinking the concept of technology in organizations. Organization Science, 3(3), 398-427.

Papacharissi, Z., \& Rubin, A. M. (2000). Predictors of Internet use. Journal of Broadcasting \& Electronic Media, 44(2), 175.

Quan-Haase, A., Wellman, B., Witte, J., \& Hampton, K. N. (2002). Capitalizing on the net: Social contact, civic engagement and sense of community. In B. Wellman \& C. A. Haythornthwaite (Eds.), The Internet in everyday life (pp. 291-324). Malden, MA: Blackwell Pub.

Raban, Y., \& Brynin, M. (2006). Older people and new technologies. In R. E. Kraut, M. Brynin, \& S. Kiesler (Eds.), Computers, phones, and the Internet: Domesticating information technology (pp. 43-50). Oxford; New York: Oxford University Press.

Rainie, L., \& Bell, P. (2004). The numbers that count. New Media \& Society, 6(1), 44-54.

Rainie, L., Fox, S., Horrigan, J., Lenhart, A., \& Spooner, T. (2000). Tracking online life: How women use the Internet to cultivate relationships with family and friends. Washington, DC: The Pew Internet and American Life Project. Retrieved November 1, 2007, from http://www.pewinternet.org/pdfs/Report1.pdf 
Rainie, L., Fox, S., \& Fallows, D. (2003). The Internet and the Iraq War: How online Americans have used the Internet to learn war news, understand events, and promote their views. Washington, DC: Pew Internet \& Life Project. Retrieved May 10, 2004, from http://www.pewinternet.org/pdfs/PIP_Iraq_War_Report.pdf

Robbin, A., Courtright, C., \& Davis, L. (2004). ICTs and political life. Annual Review of Information Science and Technology, 38, 411-462. Medford, NJ: Information Today, Inc.

Robinson, J. P., \& Martin, S. (2005). IT and social change, 2000-2004: Behavioral and attitudinal evidence from the General Social Survey. Webuse \& Society, 1(8), 1-33.

Robinson, J. P., DiMaggio, P., \& Hargittai, E. (2003). New social survey perspectives on the digital divide. IT\& Society, 1(5), 1-22.

Robinson, J. P., Kestnbaum, M., Neustadtl, A., \& Alvarez, A. 2000. Mass media use and social life among Internet users. Social Science Computer Review, 18(4), 490-501.

Ruggiero, T. E. (2000). Uses and gratifications theory in the 21st century. Mass Communication \& Society, 3(1), 337.

Savolainen , R. (2002). Network competence and information seeking on the Internet: From definitions towards a social cognitive model. Journal of Documentation, 58(2), 211-226.

Suchman, L., \& Jordan, B. (1990). Interactional troubles in face-to-face survey interviews. Journal of the American Statistical Association, 85(409), 232-241.

Shah, D. V., Kwak, N., \& Holbert, R. L. (2001). "Connecting" and "disconnecting" with civic life: Patterns of Internet use and the production of social capital. Political Communication, 18(2), 141-162.

Scheufele, D.A., Nisbet, M.C., Brossard, D., \& Nisbet, E.C. (2004). Social structure and citizenship: Examining the impacts of social setting, network heterogeneity, and informational variables on political participation. Political Communication, 21(3), 315-338.

Shklovski, I., Kiesler, S., \& Kraut, R. (2006). The Internet and social interaction: A meta-analysis and critique of studies, 1995-2003. In R. E. Kraut, M. Brynin \& S. Kiesler (Eds.), Computers, phones, and the Internet: Domesticating information technology (pp. 251-264). Oxford; New York: Oxford University Press.

Stafford, T. F., Stafford, M. R., \& Schkade, L. L. (2004). Determining uses and gratifications for the Internet. Decision Sciences, 35(2), 259-287.

Stanley, L. D. (2003). Beyond access: Psychosocial barriers to computer literacy. The Information Society, 19(5), 407 - 416.

Stempel III, G. H., Hargrove, T., \& Bernt, J. P. (2000). Relation of growth of use of the Internet to changes in media use from 1995 to 1999. Journalism \& Mass Communication Quarterly, 77(1), 71-79.

van Dijk, J. A. G. M. (2005). The deepening divide: Inequality in the information society. Thousand Oaks, Calif.: Sage Pub.

van Dijk, J., \& Hacker, K. (2003). The digital divide as a complex and dynamic phenomenon. The Information Society, 19, 315-326.

Wellman, B. (2004). The three ages of Internet studies: Ten, five and zero years ago. New Media \& Society, 6(1), 123-129.

Wellman, B., \& Haythornthwaite, C. A. (Eds.). (2002). The Internet in everyday life. Malden, MA: Blackwell Publishers. 
Table 1

Antecedents of Online Activity for Internet Users: Years Online and Location, March 2000-November 2004 (Percentaged Data)

\begin{tabular}{|c|c|c|c|c|c|c|c|c|}
\hline $\begin{array}{l}\text { Online } \\
\text { Antecedents }\end{array}$ & $\begin{array}{l}\text { Mar } \\
2000\end{array}$ & $\begin{array}{l}\text { Nov } \\
2000\end{array}$ & $\begin{array}{l}\text { Mar } \\
2001^{*}\end{array}$ & $\begin{array}{l}\text { Mar- } \\
\text { May } \\
2002\end{array}$ & $\begin{array}{l}\text { Nov } \\
2002\end{array}$ & $\begin{array}{l}\text { Mar } \\
2003 \\
\text { (Iraq } \\
\text { War) }\end{array}$ & $\begin{array}{l}\text { Mar- } \\
\text { May } \\
2003\end{array}$ & Nov 2004 \\
\hline \multicolumn{9}{|l|}{ Years Online } \\
\hline 1 year or less & $37.7 \%$ & $28.5 \%$ & $28.2 \%$ & $16.8 \%$ & $6.0 \%$ & $7.2 \%$ & $6.8 \%$ & $4.5 \%$ \\
\hline $2-3$ years & 32.9 & 32.6 & 34.0 & 31.1 & 21.8 & 14.7 & 16.3 & 10.9 \\
\hline$>3$ years & 29.4 & 38.8 & 37.8 & 52.0 & 72.2 & 78.1 & 77.0 & 84.6 \\
\hline $\mathrm{N}$ & 1.685 & 1,573 & 855 & 2,203 & 1,687 & 916 & 1,536 & 1,298 \\
\hline \multicolumn{9}{|c|}{ Online from Home } \\
\hline >Once a day & $23.3 \%$ & $23.3 \%$ & $19.9 \%$ & $24.9 \%$ & $26.0 \%$ & $26.2 \%$ & $27.5 \$$ & $30.2 \%$ \\
\hline Once a day & 29.3 & 29.0 & 28.1 & 25.2 & 25.9 & 27.7 & 28.2 & 27.2 \\
\hline$<$ Once a wk. & 7.8 & 8.7 & 9.1 & 9.4 & 11.0 & 9.5 & 8.9 & 7.1 \\
\hline $\mathrm{N}$ & 1,354 & 1,316 & 737 & 1,948 & 1,483 & 833 & 1,383 & 1,162 \\
\hline \multicolumn{9}{|c|}{ Online from Work } \\
\hline >Once a day & $40.6 \%$ & $47.2 \%$ & $48.7 \%$ & $47.6 \%$ & $52.2 \%$ & $53.2 \%$ & $54.7 \%$ & $59.0 \%$ \\
\hline Once a day & 25.6 & 21.6 & 18.7 & 21.9 & 20.1 & 21.5 & 16.9 & 20.0 \\
\hline$<$ Once a wk & 8.9 & 7.4 & 9.1 & 8.6 & 6.4 & 6.5 & 6.3 & 5.0 \\
\hline $\mathrm{N}$ & 823 & 816 & 427 & 1,134 & 881 & 506 & 763 & 646 \\
\hline
\end{tabular}

Note: *The sample is respondents who were interviewed in March 2000 and again in March 2001. 
Table 2

Internet Users Who Engage in Traditional and Internet Media Use, March 2000 - November 2004 (Percentage data)

\begin{tabular}{|c|c|c|c|c|c|c|c|c|}
\hline Did yesterday... & $\begin{array}{l}\text { Mar } \\
2000\end{array}$ & $\begin{array}{l}\text { Nov } \\
2000\end{array}$ & $\begin{array}{l}\text { Mar } \\
2001\end{array}$ & $\begin{array}{l}\text { Mar-May } \\
2002\end{array}$ & $\begin{array}{l}\text { Nov } \\
2002\end{array}$ & $\begin{array}{c}\text { Mar } \\
2003 \\
\text { (Iraq } \\
\text { War) }\end{array}$ & $\begin{array}{l}\text { Mar- } \\
\text { May } \\
2003\end{array}$ & $\begin{array}{l}\text { Nov } \\
2004\end{array}$ \\
\hline $\begin{array}{l}\text { Went online or } \\
\text { checked email }\end{array}$ & $59.6 \%$ & $56.7 \%$ & $64.5 \%$ & $58.5 \%$ & $58.6 \%$ & $59.1 \%$ & $60.8 \%$ & $62.1 \%$ \\
\hline $\begin{array}{l}\text { Read a daily } \\
\text { newspaper }\end{array}$ & 43.4 & 45.1 & 50.6 & 41.3 & 42.4 & $\mathrm{~N} / \mathrm{A}^{\wedge}$ & 42.7 & 42.4 \\
\hline Watch the news on TV & 56.0 & 71.9 & 62.5 & 59.6 & 62.2 & $N / A^{\wedge}$ & 62.7 & 64.0 \\
\hline $\mathrm{N}$ & 1,690 & 1,577 & 862 & 2,259 & 1,707 & 929 & 1,555 & 1,324 \\
\hline
\end{tabular}

Note: *The sample is respondents were interviewed in March 2000 and again in March 2001. Text of questions: "Now I have a few questions about whether you spent any time reading or watching the NEWS yesterday? Just thinking about YESTERDAY, did you get a chance to read a daily newspaper, or not?" "Did you watch the news or a news program on television yesterday, or not?” “Did you happen to go online or check your email yesterday?” Questions not asked for March 2003 Iraq War tracking survey. 
Table 3

Binary Logistic Regression for Parameters Predicting Get News Online, 2000-2004

\begin{tabular}{|c|c|c|c|c|c|c|c|c|}
\hline & Mar 2000 & Nov 2000 & Mar 2001 & $\begin{array}{c}\text { March-May } \\
2002 \\
\end{array}$ & Nov 2002 & $\begin{array}{c}\text { Mar } 2003 \\
\text { (Iraq } \\
\text { War) } \\
\end{array}$ & $\begin{array}{c}\text { Mar- } \\
\text { May } 2003 \\
\end{array}$ & Nov 2004 \\
\hline \multicolumn{9}{|l|}{ Demographics } \\
\hline Female & $-0.524 * * *$ & $-0.338 * *$ & -0.190 & $-0.221 *$ & $-0.322 * *$ & -0.242 & -0.139 & -0.194 \\
\hline \multicolumn{9}{|l|}{ Race (White=Ref. category) } \\
\hline African-American & $0.632 * *$ & -0.081 & -0.082 & -0.073 & $1.107 * * *$ & -0.154 & 0.435 & 0.125 \\
\hline Hispanic & -0.076 & 0.115 & 0.293 & -0.128 & 0.378 & -0.121 & -0.135 & 0.134 \\
\hline Other & 0.411 & 0.017 & -0.406 & $0.753^{* *}$ & 0.559 & $-0.847^{* *}$ & 0.010 & 0.307 \\
\hline \multicolumn{9}{|c|}{ Education (High School=Ref. category) } \\
\hline Less than High School & 0.260 & $-0.772 * *$ & -0.087 & 0.217 & -0.405 & -0.216 & 0.097 & -0.190 \\
\hline Some college & 0.223 & 0.121 & 0.075 & $0.511 * * *$ & 0.188 & 0.071 & $0.590 * *$ & $0.521 * *$ \\
\hline College & 0.268 & 0.208 & 0.207 & $0.583 * * *$ & $0.432 * *$ & $0.480 *$ & $0.608 * *$ & $0.705^{* * *}$ \\
\hline Age & -0.007 & $-0.015 * *$ & -0.001 & $-0.008 *$ & -0.007 & $-0.027 * * *$ & $-0.020 * * *$ & $-0.021 * * *$ \\
\hline Income & $0.004 * *$ & 0.003 & 0.002 & 0.001 & 0.001 & 0.004 & 0.003 & 0.004 \\
\hline \multicolumn{9}{|l|}{ Traditional Media Use } \\
\hline Read newspaper yesterday & -0.073 & $0.284^{*}$ & $0.322 *$ & 0.119 & $0.357 * *$ & N/A & $0.371 * *$ & -0.202 \\
\hline Watch TV news yesterday & 0.159 & 0.138 & 0.242 & $0.413 * * *$ & 0.181 & N/A & 0.224 & $0.737 * * *$ \\
\hline \multicolumn{9}{|l|}{ Computer Ownership } \\
\hline Have broadband connection? & N/A & N/A & N/A & 0.116 & 0.235 & 0.233 & 0.236 & $0.479 * *$ \\
\hline \multicolumn{9}{|l|}{ Internet Usage/Skill } \\
\hline Number of years online & $0.118 * *$ & $0.093^{* *}$ & $0.167 * * *$ & $0.128 * * *$ & $0.132 * * *$ & $0.089 * *$ & $\mathbf{0 . 0 7 5} * *$ & $0.075^{* *}$ \\
\hline Go online at home once or more & $0.492 * * *$ & $0.664 * * *$ & $0.481 * *$ & $0.542 * * *$ & $0.758 * * *$ & $0.929 * * *$ & $0.698 * * *$ & $0.621 * * *$ \\
\hline Chi-square & 68.08 & 72.19 & 43.17 & 144.21 & 130.28 & 72.05 & 92.53 & 128.92 \\
\hline Degrees of freedom & 13.00 & 13.00 & 13.00 & 14.00 & 14.00 & 12.00 & 14.00 & 14.00 \\
\hline $\mathrm{N}$ & 1,077 & 1,063 & 615 & 1,563 & 1,166 & 699 & 1,116 & 964 \\
\hline
\end{tabular}

Note: Too few respondents having broadband to be included in the regression until the 2002 survey year. The March 2003 Iraq war questionnaire did not ask about traditional media use in general. Respondents in March 2001 were interviewed in March 2000. See fn. 6 for how income and years online were coded.

Numbers in bold indicate significant values.

${ }^{*} \mathrm{p}<0.10,{ }^{* *} \mathrm{p}<.05, * * * \mathrm{p}<.001$ 
Table 4

Binary Logistic Regression for Parameters Predicting Buy a Product Online, 2000-2004

\begin{tabular}{|c|c|c|c|c|c|c|c|}
\hline & Mar 2000 & Nov 2000 & Mar 2001 & $\begin{array}{c}\text { March-May } \\
2002 \\
\end{array}$ & $\begin{array}{c}\text { November } \\
2002 \\
\end{array}$ & $\begin{array}{c}\text { March } \\
2003 \text { (Iraq } \\
\text { War) } \\
\end{array}$ & $\begin{array}{c}\text { March-May } \\
2003 \\
\end{array}$ \\
\hline \multicolumn{8}{|l|}{ Demographics } \\
\hline Female & 0.129 & $0.239 *$ & $0.382 * *$ & $0.197 *$ & $0.272 * *$ & -0.157 & $0.427 * *$ \\
\hline \multicolumn{8}{|l|}{ Race (White=Ref. category) } \\
\hline African-American & $-0.771 * * *$ & 0.041 & 0.609 & -0.144 & -0.360 & -0.570 & -0.287 \\
\hline Hispanic & -0.076 & -0.183 & -0.368 & -0.247 & $-0.556 * *$ & $-0.599 *$ & -0.293 \\
\hline Other & $-0.704^{* *}$ & -0.109 & 0.588 & 0.112 & 0.052 & 0.061 & $-0.665^{*}$ \\
\hline \multicolumn{8}{|c|}{ Education (High School=Ref. category) } \\
\hline Less than High School & -0.236 & -0.150 & -1.157 & -0.447 & -0.189 & 0.077 & -0.490 \\
\hline Some college & 0.204 & $0.393 * *$ & 0.147 & $0.378 * *$ & $0.534 * *$ & $0.407^{*}$ & 0.125 \\
\hline College & $0.542 * * *$ & $0.547 * *$ & 0.252 & $0.597 * * *$ & $0.766 * * *$ & $0.714 * *$ & $0.613 * * *$ \\
\hline Age & -0.006 & $-0.015 * *$ & $-0.018 * *$ & $-0.021 * * *$ & $-0.014 * *$ & $-0.021 * * *$ & $-0.019 * * *$ \\
\hline Income & $0.006 * * *$ & $0.009 * * *$ & $0.008 * *$ & $0.008 * * *$ & $0.006 * *$ & $0.009 * *$ & $0.009 * * *$ \\
\hline \multicolumn{8}{|l|}{ Traditional Media Use } \\
\hline Read newspaper yesterday & -0.109 & 0.009 & 0.303 & 0.084 & 0.089 & N/A & 0.240 \\
\hline Watch TV news yesterday & 0.112 & -0.045 & -0.248 & $-0.265^{* *}$ & 0.056 & N/A & -0.173 \\
\hline \multicolumn{8}{|l|}{ Computer Ownership } \\
\hline Have broadband connection? & N/A & N/A & N/A & $0.398 * *$ & $0.465 * *$ & $0.009 *$ & 0.123 \\
\hline \multicolumn{8}{|l|}{ Internet Usage/Skill } \\
\hline Number of years online & $0.178 * * *$ & $0.189 * * *$ & $0.208 * * *$ & $0.119 * * *$ & $0.094^{* * *}$ & $0.079 * *$ & $0.110 * * *$ \\
\hline Go online at home once or more & $0.574 * * *$ & $0.653 * * *$ & $0.324 *$ & $0.620 * * *$ & $0.384 * *$ & $0.755^{* * *}$ & $0.581 * * *$ \\
\hline Chi-square & 107.85 & 123.73 & 76.86 & 216.65 & 126.22 & 86.79 & 149.07 \\
\hline Degrees of freedom & 13.00 & 13.00 & 13.00 & 14.00 & 14.00 & 12.00 & 14.00 \\
\hline $\mathrm{N}$ & 1,077 & 1,064 & 616 & 1,565 & 1,167 & 698 & 1,117 \\
\hline
\end{tabular}

Note: Too few respondents have broadband access to be included in the regression until 2002. Buying a product online was not asked in the

November 2004 survey. The March 2003 Iraq war questionnaire did not ask about traditional media use in general. Respondents interviewed in March 2001 were first interviewed in March 2000. See fn. 6 for how income and years online were coded. Numbers in bold indicate significant values.

${ }^{*} \mathrm{p}<0.10, * * \mathrm{p}<.05, * * * \mathrm{p}<.001$ 
Table 5

Binary Logistic Regression for Parameters Predicting Go Online to Pass the Time, 2000-2004

\begin{tabular}{|c|c|c|c|c|c|}
\hline & $\begin{array}{l}\text { March } \\
2000\end{array}$ & $\begin{array}{c}\text { November } \\
2000\end{array}$ & $\begin{array}{l}\text { March } \\
2001\end{array}$ & $\begin{array}{l}\text { March } 2003 \\
\text { (Iraq war) }\end{array}$ & $\begin{array}{c}\text { March- } \\
\text { May } 2003\end{array}$ \\
\hline \multicolumn{6}{|l|}{ Demographics } \\
\hline Female & 0.075 & 0.079 & -0.062 & $-0.309 *$ & -0.010 \\
\hline \multicolumn{6}{|l|}{ Race (White=Ref. category) } \\
\hline African-American & 0.218 & 0.401 & 0.612 & 0.112 & 0.207 \\
\hline Hispanic & -0.019 & 0.234 & -0.307 & -0.203 & -0.156 \\
\hline Other & -0.264 & -0.451 & 0.427 & -0.427 & 0.075 \\
\hline \multicolumn{6}{|c|}{ Education (High School=Ref. category) } \\
\hline Less than High School & $1.061^{*}$ & 0.042 & 0.550 & 0.256 & 0.388 \\
\hline Some college & -0.115 & $-0.501 * *$ & -0.392 & $-0.540 * *$ & -0.251 \\
\hline College & $-0.481 * *$ & $-0.911^{* * *}$ & $-0.657 * *$ & $-0.507^{* *}$ & $-0.595 * *$ \\
\hline Age & $-0.016 * *$ & $-0.024 * * *$ & -0.012 & $-0.037 * * *$ & $-0.019 * * *$ \\
\hline Income & -0.003 & $-0.004^{*}$ & $-0.008 * *$ & -0.002 & $-0.004 * *$ \\
\hline \multicolumn{6}{|l|}{ Traditional Media Use } \\
\hline Read newspaper yesterday & -0.070 & -0.088 & -0.052 & N/A & 0.042 \\
\hline Watch TV news yesterday & 0.201 & 0.170 & $0.396 * *$ & N/A & -0.034 \\
\hline \multicolumn{6}{|l|}{ Computer Ownership } \\
\hline Have broadband connection? & N/A & N/A & N/A & 0.218 & $0.580 * * *$ \\
\hline \multicolumn{6}{|l|}{ Internet Usage/Skill } \\
\hline Number of years online & 0.030 & -0.050 & -0.010 & $-0.068 * *$ & 0.004 \\
\hline Go online at home once or more & $0.542 * * *$ & $0.344^{* *}$ & $0.702 * * *$ & $0.650^{* * *}$ & $0.327^{* *}$ \\
\hline Chi-square & 73.05 & 89.51 & 51.01 & 72.69 & 71.59 \\
\hline Degrees of freedom & 13.0 & 13.00 & 13.00 & 12.00 & 14.00 \\
\hline $\mathrm{N}$ & 1077 & 1063 & 615 & 696 & 1117 \\
\hline
\end{tabular}

Note: Going online to pass the time was not asked in the 2002 and 2004 surveys that we analyzed. There were too few respondents that had broadband access to be included in the regression until the 2002 survey year. The March 2003 Iraq War questionnaire did not ask about traditional media use in general. Respondents were interviewed in March 2000 and again in March 2001. See fn. 6 for how income and years online were coded. Numbers in bold indicate significant values.

${ }^{*} \mathrm{p}<0.10,{ }^{* *} \mathrm{p}<.05,{ }^{* * *} \mathrm{p}<.001$ 
Table A2

Percentage Rates of Internet Activities by Survey Year, 2000-2004

\begin{tabular}{|c|c|c|c|c|c|c|c|c|}
\hline Internet Activity & $\begin{array}{l}\text { Mar } \\
2000\end{array}$ & $\begin{array}{l}\text { Nov } \\
2000\end{array}$ & $\begin{array}{c}\text { Mar } \\
2001^{*}\end{array}$ & $\begin{array}{l}\text { Mar } \\
2002\end{array}$ & $\begin{array}{l}\text { Nov } \\
2002\end{array}$ & $\begin{array}{l}\text { Mar } \\
2003 \\
\text { Iraq War }\end{array}$ & $\begin{array}{l}\text { Mar-Apr } \\
2003\end{array}$ & $\begin{array}{l}\text { Nov } \\
2004\end{array}$ \\
\hline Buy a product online, such as books, music, toys or clothing & $47.6 \%$ & $50.9 \%$ & $54.6 \%$ & $55.6 \%$ & $61.5 \%$ & & $62.7 \%$ & \\
\hline Buy groceries, food, or other household products online & & & & & & & 12.5 & \\
\hline $\begin{array}{l}\text { Buy or make a reservation for a travel service, like an airline ticket, } \\
\text { hotel room, or rental car }\end{array}$ & 36.3 & & 44.5 & & & & & \\
\hline Buy or sell stocks, mutual funds or bonds & 12.8 & 14.8 & 13.0 & 13.8 & & & & \\
\hline Check sports scores and information & 35.6 & 38.4 & 32.8 & & & & & \\
\hline Check weather reports and forecasts & 61.2 & 64.2 & & 69.2 & & & & \\
\hline Create a web log or "blog” that others can read on the web & & & & & & & & 5.9 \\
\hline $\begin{array}{l}\text { Create content for the Internet, such as helping build a website, } \\
\text { creating an online diary, or posting your thoughts to an online } \\
\text { bulletin board or other online community }\end{array}$ & & & & & & & & 17.8 \\
\hline $\begin{array}{l}\text { Do an Internet search to find the answer to a specific question you } \\
\text { have }\end{array}$ & & 78.4 & & & & & & \\
\hline Do any banking online & 17.9 & & 23.0 & 29.6 & & & & \\
\hline Do research for school or training & 56.0 & 52.8 & & & & & & \\
\hline $\begin{array}{l}\text { Download music files onto your computer so you can play them at } \\
\text { any time you want }\end{array}$ & & 24.6 & & & & & & \\
\hline $\begin{array}{l}\text { Get financial information such as stock quotes or mortgage interest } \\
\text { rates }\end{array}$ & 44.6 & 46.3 & 44.4 & & & 48.2 & 45.6 & \\
\hline $\begin{array}{l}\text { Get information about travel, such as checking airline ticket prices } \\
\text { or hotel rates }\end{array}$ & 64.1 & & 67.2 & & & & 57.4 & \\
\hline Get news online & 59.9 & 64.2 & 60.2 & 66.8 & 67.7 & 73.6 & 74.8 & 69.2 \\
\hline $\begin{array}{l}\text { Go online for no particular reason, just for fun or to pass the } \\
\text { time }\end{array}$ & 62.1 & 65.7 & 58.2 & & & 64.4 & 64.4 & \\
\hline Listen to or download music & 35.6 & & 32.0 & & & & 27.2 & \\
\hline Look for health or medical information & 53.8 & 58.9 & 60.4 & 61.7 & 66.4 & & & \\
\hline Look for information about a hobby or interest & 76.0 & 78.6 & 76.7 & & & 79.7 & 75.5 & \\
\hline Look for information about a job & 38.1 & & 35.6 & 45.4 & & & 41.2 & \\
\hline
\end{tabular}




\begin{tabular}{|c|c|c|c|c|c|c|c|c|}
\hline Internet Activity & $\begin{array}{c}\text { Mar } \\
2000\end{array}$ & $\begin{array}{l}\text { Nov } \\
2000\end{array}$ & $\begin{array}{c}\text { Mar } \\
2001^{*}\end{array}$ & $\begin{array}{l}\text { Mar } \\
2002\end{array}$ & $\begin{array}{l}\text { Nov } \\
2002\end{array}$ & $\begin{array}{c}\text { March } \\
2003 \\
\text { Iraq War }\end{array}$ & $\begin{array}{l}\text { Mar-Apr } \\
2003\end{array}$ & $\begin{array}{l}\text { Nov } \\
2004\end{array}$ \\
\hline Look for information about/on a place to live & 27.2 & & 26.1 & 35.7 & & & 34.5 & \\
\hline $\begin{array}{l}\text { Look for information about a product or service you are thinking } \\
\text { about buying }\end{array}$ & 73.6 & & 74.7 & & & 63.6 & & \\
\hline $\begin{array}{l}\text { Look for information about movies, music, books, or other leisure } \\
\text { activities }\end{array}$ & 62.5 & & 60.8 & 72.3 & & & & \\
\hline $\begin{array}{l}\text { Look for information from a local, state, or federal government } \\
\text { web site }\end{array}$ & 47.5 & & 58.7 & 60.0 & 57.6 & 63.6 & 65.9 & 56.7 \\
\hline Look for news or information about politics and the campaign & 35.7 & 51.0 & & & 41.1 & & & 57.6 \\
\hline Look for religious or spiritual information & 21.6 & & 25.1 & & 29.7 & 26.7 & 29.3 & \\
\hline Make a phone call online, using the Internet & & & 11.8 & & & & & \\
\hline $\begin{array}{l}\text { Not including email, do any type of work or research online for } \\
\text { your job }\end{array}$ & 49.5 & 51.3 & 49.4 & & 53.6 & & & \\
\hline Participate in an online auction & 14.7 & & 19.6 & 20.2 & & & & \\
\hline Play a game online & 34.0 & & 32.1 & 34.4 & & & 37.8 & \\
\hline Play a lottery or gamble online & 4.7 & & & & & & 3.2 & \\
\hline Read someone else's web log or blog & & & & & & & & 27.2 \\
\hline Research your family’s history or genealogy & & & 19.6 & & & & 24.2 & \\
\hline $\begin{array}{l}\text { Search for information on the Internet about someone you know or } \\
\text { might meet }\end{array}$ & & & & 27.6 & & & & \\
\hline Send "instant messages" to someone who's online at the same time & 44.7 & & 41.9 & & & & 45.0 & \\
\hline Send or read email & 91.0 & 92.4 & 92.7 & 93.5 & 93.9 & 94.0 & 93.3 & 93.8 \\
\hline $\begin{array}{l}\text { Send or receive an invitation to a meeting or party using an online } \\
\text { invitation service like Meetup or E-vite }\end{array}$ & & & & & & & & 14.2 \\
\hline Take a class online for college credit & & & & 6.7 & & & & \\
\hline Take any other class online & & & & 6.3 & & & & \\
\hline Take part in "chat rooms" or online discussions with other people & 28.0 & & & & & & & \\
\hline Visit adult websites & & & 13.0 & & & & & \\
\hline Watch a video clip or listen to an audio clip & 47.6 & & 47.7 & & & & 50.6 & \\
\hline
\end{tabular}


Table A3

Selected Demographic Characteristics of Internet and Non-Internet Users, March 2000 November 2004 (Percentaged Data)

\begin{tabular}{|c|c|c|c|c|c|c|c|c|}
\hline $\begin{array}{l}\text { Demographic } \\
\text { Characteristics }\end{array}$ & $\begin{array}{l}\text { Mar } \\
2000\end{array}$ & $\begin{array}{l}\text { Nov } \\
2000\end{array}$ & $\begin{array}{c}\text { Mar } \\
2001^{*}\end{array}$ & $\begin{array}{l}\text { Mar- } \\
\text { May } \\
2002\end{array}$ & $\begin{array}{l}\text { Nov } \\
2002\end{array}$ & $\begin{array}{l}\text { Mar } \\
2003 \\
\text { (Iraq } \\
\text { War) }\end{array}$ & $\begin{array}{l}\text { Mar- } \\
\text { May } \\
2003\end{array}$ & $\begin{array}{l}\text { Nov } \\
2004\end{array}$ \\
\hline \multicolumn{9}{|c|}{$\%$ of Internet Users } \\
\hline Female & 49.3 & 47.0 & 53.2 & 48.9 & 49.4 & 46.1 & 50.3 & 51.2 \\
\hline African-American & 9.0 & 7.6 & 5.3 & 6.7 & 8.1 & 5.9 & 7.7 & 9.0 \\
\hline Hispanic & 7.5 & 6.5 & 6.1 & 7.3 & 7.1 & 7.5 & 6.0 & 5.4 \\
\hline Average Age & 37.7 & 38.7 & 43.3 & 40.5 & 40.1 & 42.3 & 42.4 & 44.3 \\
\hline$<\$ 20,000$ & 10.0 & 10.5 & 7.2 & 9.1 & 9.6 & 7.0 & 10.2 & 10.6 \\
\hline College or more & 40.4 & 41.4 & 44.9 & 41.6 & 39.6 & 46.2 & 43.3 & 44.7 \\
\hline $\mathrm{N}$ & 1,690 & 1,577 & 862 & 2,259 & 1,707 & 929 & 1,555 & 1,324 \\
\hline \multicolumn{9}{|c|}{$\%$ of Non-Internet Users } \\
\hline Female & 56.8 & 54.4 & 62.0 & 56.7 & 53.4 & 50.3 & 56.5 & 56.1 \\
\hline African-American & 13.5 & 11.5 & 9.3 & 12.7 & 11.4 & 9.3 & 11.0 & 14.3 \\
\hline Hispanic & 9.2 & 8.8 & 4.6 & 6.4 & 7.8 & 7.7 & 7.3 & 7.9 \\
\hline Average Age & 50.4 & 52.9 & 58.4 & 56.0 & 56.4 & 54.9 & 56.3 & 57.2 \\
\hline$<\$ 20,000$ & 31.0 & 32.8 & 35.7 & 33.4 & 34.8 & 32.1 & 32.8 & 33.9 \\
\hline College or more & 14.6 & 15.0 & 16.5 & 13.0 & 14.4 & 16.1 & 15.3 & 16.8 \\
\hline $\mathrm{N}$ & 1,843 & 1,171 & 639 & 1,294 & 1,038 & 561 & 960 & 876 \\
\hline
\end{tabular}

Note: *Respondents were interviewed in March 2000 and again in March 2001 
Table A4

Information Utility Factor for Survey Years, 2000-2004

\begin{tabular}{|c|c|c|}
\hline Survey & Internet Activities & $\begin{array}{l}\text { Factor } \\
\text { loading }\end{array}$ \\
\hline \multirow[t]{5}{*}{ March 2000} & Get news online & 0.634 \\
\hline & Check weather reports and forecasts & 0.628 \\
\hline & Look for news or information about politics and the campaign & 0.614 \\
\hline & Look for helth or medical information & 0.492 \\
\hline & Check sports scores and information & 0.462 \\
\hline \multirow[t]{4}{*}{ November 2000} & Get news online & 0.754 \\
\hline & Look for news or information about politics and the campaign & 0.709 \\
\hline & Check sports scores and information & 0.603 \\
\hline & Check weather reports and forecasts & 0.548 \\
\hline \multirow[t]{5}{*}{ March 2001} & Look for information about movies, music, books, or other leisure activities & 0.600 \\
\hline & Look for information about a hobby or interest & 0.594 \\
\hline & Look for information about a product or service you are thinking about & \\
\hline & buying & 0.549 \\
\hline & Get news online & 0.524 \\
\hline \multirow[t]{5}{*}{ March 2002} & Check weather reports and forecasts & 0.701 \\
\hline & Get news online & 0.687 \\
\hline & Look for health or medical information & 0.605 \\
\hline & Look for information from a local, state, or federal government web site & 0.526 \\
\hline & Look for information about movies, music, books, or other leisure activities & 0.422 \\
\hline \multirow[t]{5}{*}{ November 2002} & Not including email, do any type of work or research online for your job & 0.666 \\
\hline & BUY a product online, such as books, music, toys or clothing & 0.605 \\
\hline & Look for information from a local, state, or federal government web site & 0.604 \\
\hline & Get news online & 0.541 \\
\hline & Look for news or information about politics and the campaign & 0.533 \\
\hline \multirow[t]{5}{*}{ March 2003 (Iraq War) } & Look for information from a local, state, or federal government web site & 0.662 \\
\hline & Get financial information such as stock quotes or mortgage interest rates & 0.625 \\
\hline & BUY a product online, such as books, music, toys or clothing & 0.561 \\
\hline & Look for religious or spiritual information & 0.509 \\
\hline & Get news online & 0.488 \\
\hline \multirow[t]{3}{*}{ March-May 2003} & Research your family's history or genealogy & 0.679 \\
\hline & Look for religious or spiritual information & 0.600 \\
\hline & Get news online & 0.406 \\
\hline \multirow[t]{3}{*}{ November 2004} & Look for news or information about politics and the campaign & 0.800 \\
\hline & Get news online & 0.723 \\
\hline & Look for information from a local, state, or federal government web site & 0.682 \\
\hline
\end{tabular}

Note: Factor loadings with a weight less than 0.40 are not included in the table. The information utility factors explained the following variability in the indicators for their respective surveys: March $2000=17.9 \%$, November 2000=20.0\%, March 2001=17.8\%, March 2002=19.0\%, November 2002=30.5\%, March 2003 (Iraq War) $=28.0 \%$, March-May 2003=6.4\%, November 2004=32.3\%. 
Table A5

Leisure Factor for Survey Years, 2000-2003

\begin{tabular}{|c|c|c|}
\hline Survey & Internet Activities & $\begin{array}{l}\text { Factor } \\
\text { loading }\end{array}$ \\
\hline \multirow[t]{6}{*}{ March 2000} & Take part in "chat rooms" or online discussions with other people & 0.662 \\
\hline & Play a game online & 0.623 \\
\hline & Listen to or download music & 0.560 \\
\hline & Go online for no particular reason, just for fun or to pass the time & 0.530 \\
\hline & Send “instant messages” to someone who’s online at the same time & 0.521 \\
\hline & Watch a video clip or listen to an audio clip & 0.506 \\
\hline \multirow[t]{3}{*}{ November 2000} & Download music files onto your computer so you can play them at any time you want & 0.823 \\
\hline & Listen to or download music & 0.803 \\
\hline & Go online for no particular reason, just for fun or to pass the time & 0.356 \\
\hline \multirow[t]{5}{*}{ March 2001} & Play a game online & 0.647 \\
\hline & Listen to or download music & 0.629 \\
\hline & Go online for no particular reason, just for fun or to pass the time & 0.531 \\
\hline & Send "instant messages" to someone who's online at the same time & 0.501 \\
\hline & Watch a video clip or listen to an audio clip & 0.411 \\
\hline March 2002 & Play a game online & 0.787 \\
\hline \multirow[t]{2}{*}{ March 2003-Iraq War } & Go online for no particular reason, just for fun or to pass the time & 0.828 \\
\hline & Look for information about a hobby or interest & 0.558 \\
\hline \multirow[t]{5}{*}{ March-May 2003} & Listen to or download music & 0.663 \\
\hline & Send "instant messages" to someone who's online at the same time & 0.642 \\
\hline & Play a game online & 0.594 \\
\hline & Go online for no particular reason, just for fun or to pass the time & 0.560 \\
\hline & Watch a video clip or listen to an audio clip & 0.538 \\
\hline
\end{tabular}

Note: Factor loadings with a weight less than 0.40 are not included in the table. The transaction factors explained he following variability in the indicators for their respective surveys: March 2000 $=5.1 \%$, November 2000 $=10.3 \%$, March 2001=7.9\%, March 2002=8.8\%, November 2002=30.5\%, March 2003-Iraq War=15.1\%, March-May $2003=17.4 \%$. 
Table A6

Financial Transactions Factor for Survey Years, 2000-2003

\begin{tabular}{|c|c|c|}
\hline Survey & Internet Activities & $\begin{array}{l}\text { Factor } \\
\text { loading }\end{array}$ \\
\hline \multirow[t]{5}{*}{ March 2000} & $\begin{array}{l}\text { Buy or make a reservation for a travel service, like an airline ticket, hotel room, or } \\
\text { rental car }\end{array}$ & 0.707 \\
\hline & Get information about travel, such as checking airline ticket prices or hotel rates & 0.631 \\
\hline & BUY a product online, such as books, music, toys or clothing & 0.618 \\
\hline & Participate in an online auction & 0.468 \\
\hline & Look for information about a product or service you are thinking about buying & 0.437 \\
\hline \multirow[t]{3}{*}{ November 2000} & Buy or sell stocks, mutual funds or bonds & 0.806 \\
\hline & Get financial information such as stock quotes or mortgage interest rates & 0.704 \\
\hline & BUY a product online, such as books, music, toys or clothing & 0.438 \\
\hline \multirow[t]{5}{*}{ March 2001} & Buy or sell stocks, mutual funds or bonds & 0.693 \\
\hline & Get financial information such as stock quotes or mortgage interest rates & 0.640 \\
\hline & Do any banking online & 0.556 \\
\hline & BUY a product online, such as books, music, toys or clothing & 0.472 \\
\hline & $\begin{array}{l}\text { Buy or make a reservation for a travel service, like an airline ticket, hotel room, or } \\
\text { rental car }\end{array}$ & 0.466 \\
\hline \multirow[t]{4}{*}{ March 2002} & BUY a product online, such as books, music, toys or clothing & 0.649 \\
\hline & Do any online banking & 0.634 \\
\hline & Buy or sell stocks, mutual funds, or bonds & 0.602 \\
\hline & Participate in an online auction & 0.596 \\
\hline \multirow[t]{5}{*}{ November 2002} & Not including email, do any type of work or research online for your job & 0.666 \\
\hline & BUY a product online, such as books, music, toys or clothing & 0.605 \\
\hline & Look for information from a local, state, or federal government web site & 0.604 \\
\hline & Get news online & 0.541 \\
\hline & Look for news or information about politics and the campaign & 0.533 \\
\hline \multirow[t]{5}{*}{$\begin{array}{l}\text { March } 2003 \\
\text { (Iraq War) }\end{array}$} & Look for information from a local, state, or federal government web site & 0.662 \\
\hline & Get financial information such as stock quotes or mortgage interest rates & 0.625 \\
\hline & BUY a product online, such as books, music, toys or clothing & 0.561 \\
\hline & Look for religious or spiritual information & 0.509 \\
\hline & Get news online & 0.488 \\
\hline \multirow[t]{5}{*}{ March-May 2003} & BUY a product online, such as books, music, toys or clothing & 0.690 \\
\hline & $\begin{array}{l}\text { Buy or make a reservation for a travel service, like an airline ticket, hotel room, or } \\
\text { rental car }\end{array}$ & 0.670 \\
\hline & Buy groceries, food, or other household products online & 0.552 \\
\hline & Get financial information such as stock quotes or mortgage interest rates & 0.549 \\
\hline & Look for information from a local, state, or federal government web site & 0.437 \\
\hline
\end{tabular}

Note: Factor loadings with a weight less than 0.40 are not included in the table (except for November 2000 to show the location of the Internet activity of interest in this table). The leisure factors explained the following variability in the indicators for their respective surveys: March 2000=7.4\%, November 2000=8.5\%, March 2001=5.4\%, March 2002=7.4\%, March 2003-Iraq War=15.1\%, March-April 2003=17.4\%. 